\title{
INTERNATIONAL COMPARISONS AND TRANSFER OF LABOUR MARKET INSTITUTIONS
}

\author{
WOLFGANG OCHEL \\ CESIFO WORKING PAPER NO. 788 \\ CATEGORY 4: LABOUR MARKETS \\ OCTOBER 2002 \\ An electronic version of the paper may be downloaded \\ - from the SSRN website: www.SSRN.com \\ - from the CESifo website: www.CESifo.de
}




\title{
INTERNATIONAL COMPARISONS AND TRANSFER OF LABOUR MARKET INSTITUTIONS
}

\begin{abstract}
International comparisons of labour market institutions and their transfer across boundaries have gained in importance. The paper deals with the question of the best way to proceed in making such comparisons. At the same time the question of the possibilities and limits to institutional transfer is addressed. On the one hand competition between systems obliges governments to adopt institutions of other countries. On the other hand inflexibilities resulting from path dependency and/or powerful domestic interest groups can impede the transfer of institutions.
\end{abstract}

JEL Classification: J38, J58, J68, K31, N40, P51.

\author{
Wolfgang Ochel \\ Ifo Institute \\ Poschingerstr. 5 \\ 81679 Munich \\ Germany \\ ochel@ifo.de
}


Wolfgang Ochel

\section{International Comparisons and Transfer of Labour Market Institutions}

\section{Introduction}

Political decision makers hope that international comparisons of institutions will give them insights that will help to improve decision making in their own country. They wish to know what institutional arrangements have been chosen by other countries and whether the arrangements chosen have given desirable results. Under certain circumstances they would then transfer such arrangements to their own country. In this context the question arises of the best way to proceed in making such comparisons; at the same time the question of the possibilities of and limits to institutional transfer should be addressed.

The following contribution deals with these two questions. Sections 2 and 3 explain why international comparisons of institutions have gained in importance in the last 20 years and what objectives are pursued in these comparisons. In the following section (4) the reasons why countries introduce institutional arrangements are examined and, in section 5, the question is discussed, how one can take into account these arrangements. This analysis is carried forward in section 6 which shows how arrangements leading to desirable results can be identified. In this connection, aggregated analysis of effects as well as microeconomic evaluation is employed (sections 7 and 8). One must not lose sight of the fact that comparisons of institutions are not made for their own sake, but are a preliminary step toward the international transfer of appropriate institutions. Section 9 deals with the question, to what extent competition between systems obliges governments to adapt institutions from other countries. Finally, sections 10 and 11 contain a discussion of the question, to what extent path dependent inflexibilities and/or powerful domestic interest groups can impede the transfer of institutions. Labour market institutions are at the centre of this discussion.

\section{International Comparison of Institutions: A Modern Basis for Political Decisions}

The way an economy works is determined decisively by its institutions. Institutions regulate social life. They impose limits to individual comportment and steer it into certain channels. They contribute to the stabilisation of expectations. Among the institutions one finds the market, the laws of the state, government regulations, and court decisions, agreements between interest groups, as well as norms, customs, and value judgements shared by the members of society (Regini 2000, p. 22). The following remarks focus on regulations emanating from the state (e.g. legal dispositions regulating 
the termination of employment) and on agreements between interest groups (e.g. wage agreements between employers and trade unions).

Laying down institutional arrangements has always been a primordial responsibility of the state. In fulfilling this responsibility, governments have always had in mind the arrangements prevailing in other countries. Since the beginning of the 1980s, however, so-called benchmarking has gained considerably in importance. In view of the "eurosclerosis" that has been diagnosed a debate has begun on the advantages and disadvantages of Europe as a place to live or work or conduct a business. In this debate, great attention has been given to differences with respect to state regulation between European states, and especially as compared to the United States. Margaret Thatcher began in Great Britain a comprehensive process of deregulation which resulted inter alia in the flexibilisation of the labour market. Later, Tony Blair adapted the American welfare to work approach. Similar benchmarking processes can be observed in other areas in almost all EU countries (Tronti 1998). And in transformation economies, as well, governments have been eager to adapt institutional set-ups of western countries that seem to promise success. In carrying out benchmarking studies, international organisations such as the OECD, the Commission of the EU and the International Labour Office (ILO) support individual countries in their efforts to carry out international comparisons and to identify best practices.

The increasing importance of international comparisons of institutions in recent years is due to a number of factors. As a result of globalisation, locational competition is becoming more intense. State regulations are becoming increasingly more important as a locational factor for enterprises that operate internationally. Governments are thus competing against each other in the attempt to develop an institutional framework that is as attractive as possible. The growth of international integration means that increasingly 'national' economies are subject to similar shocks. This provides a better basis for evaluating the ability of national institutional arrangements to cope with such shocks. Institutional learning, which is facilitated by improvements in communications, is developing into an important foundation for political decisions (Dolowitz and Marsh 2000).

Another reason for the increasing importance of international comparisons of institutions is to be seen in the on-going dissolution of the original ideological foundations of the modern welfare state. This means that the traditional sources of legitimation for the state's economic policies are increasingly called into question. On the other hand, established ideological positions are less and less a hindrance to adapting other countries' ideas and institutional arrangements. A pragmatic attitude is becoming more and more common. Politicians look increasingly to those states which have the status of a role model. Other countries' successful institutional arrangements serve to legitimise institutional change in one's own country (Cox 1999; Strassheim 2001). 


\section{Objectives of an International Comparison of Institutions}

The international comparison of institutions forms an important part of political benchmarking. With respect to labour market policy questions, it is directed at determining which institutional arrangements have been the basis for success in the labour market and which have proven to be counter-productive. Although this task appears at first glance to be simple, it is, in fact, very complex (Schütz et al. 1998).

Learning from other countries involves finding out what shape other countries have given to their institutional arrangements. It is also of interest to know to what extent the institutional arrangements find practical application, or whether they exist mainly on paper. The institutional learning is also directed at organisations which are concerned with the adaptation and implementation of institutions. But institutional learning ought not to be content with merely taking stock. In many cases it will prove important to ascertain as well the reasons and the immediate cause for the introduction of specific institutional arrangements. Only when this is known will it be possible to determine whether the motives for the foreign arrangement are analogous to the problems at home for which one seeks a solution. The degree of congruence in the objectives pursued casts light on the question whether the regulatory model will be of use in attaining a given goal (Bamber and Lansbury 1998, p. 2).

Of course, learning from other countries should not be confined to the consideration of the nature of institutional arrangements, but must also include the consideration of their effectiveness. This requires a process of evaluation. This must be done on the basis of appropriate indicators of performance. Furthermore, in carrying out the evaluation, the possibility that complementary relationships with other institutional arrangements may exist must be taken into account. And finally, one must take into consideration the nature of the shocks to which the country examined was exposed during the period under review.

The relationship between institutional arrangements and certain indicators of performance can not only be determined for individual countries in isolation, but can also be based on studies that go beyond one country. These relate performance as measured by certain indicators to differences in the regulatory approach of the countries being studied. In some cases, changes in the system of regulation over time are taken into account (Boeri et al. 2000).

\section{Reasons Why Institutional Arrangements Are Introduced}

In carrying out an international comparison, it is useful to know of the reasons that have lead to the introduction of new institutional arrangements, or to the modification of existing arrangements. Three categories of causes may be identified. First, state institutions are created in order to reduce inefficiencies resulting from market failure. (It goes without saying that action by the state is only called for if one can exclude the 
possibility that the state's intervention will give rise to new and even more serious inefficiencies.) Second, institutional arrangements are initiated in order to correct the distribution solution found by the market. And finally, interest groups attempt to influence the institutional framework in pursuance of their own advantage.

Market failure can arise owing to monopoly power, to external effects or to asymmetrical information. If it is an employer who is exercising monopoly power (e.g. if a certain enterprise is by far the largest employer in a region), then when profits are at a maximum, the wage rate will lie under the marginal product of labour. The level of employment will be lower than it should be and could be raised by fixing a minimum wage higher than the prevailing wage (and as close as possible to the equilibrium wage) (Stigler 1946). If it is the employees who are exercising monopoly power, then an improvement in efficiency could be attained by permitting exceptions in the wage agreement.

In the case of external effects, misleading incentives can be avoided by setting up institutional arrangements resulting in the external effects being internalised. If for example vocational training and qualification measures are not carried out by enterprises because they find that they can obtain all the labour they require by recruiting employees from other firms, then imposing a penalty for non-compliance with vocational training requirements can provide partial compensation for this externality (Addison and Siebert 1999, p. 43ff.).

A further cause of market failure can lie in the enterprise's ignorance of the characteristics of its employees or of those applying for a job. As a result, an individual enterprise might, for example, be reluctant to offer its employees maternity leave, since it sees the risk that among its women applicants for jobs there might be an above average proportion of pregnant women, which it would have no way of identifying before hiring. Owing to the risk of adverse selection, employees will therefore not be willing to offer maternity leave. Only when the state obliges all employers to grant maternity leave, does the problem of adverse selection resolve itself and the desired establishment of maternal leave can take place (Blau and Kahn 1999, p. 1405; Addison and Siebert 1999, p. 46 ff.).

Besides regulations which aim at increasing efficiency, institutions are created in order to correct the distribution brought about by the market and to increase income security. Central wage negotiations are often introduced with a view toward reducing wage disparities. Social security systems have among other things the goal of guaranteeing a secure income in cases of need (Agell 2000).

Institutional arrangements are not, however, always directed at improving the economic welfare of the general public by means of improvements in efficiency or in income distribution. Often enough, the motive force behind such arrangements are powerful interest groups, which are keen on obtaining their own advantages. Either they have the authority, together with other interest groups, to define the arrangements in certain areas. Or they make use of their influence to ensure that the state, in its laws or administrative edicts, take into account its interests. The provisions protecting 
jobholders against unjust dismissal offer an example of an institutional arrangement that is driven by these kinds of interests. This protection works to the advantage of the 'insiders' (the employed), at the cost of the 'outsiders' (the unemployed). Thus the job security enjoyed by the insiders is enhanced, which permits them to push through higher wage demands without the risk of losing their employment. The larger the group of insiders is, the easier it is for them to protect their interests (Saint-Paul 2000).

\section{Capturing the Institutional Arrangements of Other Countries}

The first step in carrying out an international comparison of institutions is to choose the countries with which the institutions of a particular country are to be compared. A country's institutional networks are influenced by the political environment (dictatorship, democracy), by the economic system (planned, market economy), by the stage of development in which the country finds itself (developing, threshold, industrialised economy), by the prevailing culture of regulation (formal vs. informal regulation) of the country, to name only the most important influences. Institutional learning is as a rule only possible, when the countries used for comparison exhibit similar characteristics. For this reason, highly developed market economies should be compared with each other. Moreover, it should be taken into account that within this larger group there are sub-groups of countries whose institutional networks show common characteristics differing in some respects from those of the larger group (cf. Esping-Andersen 1996).

The next question is, what institutions should be compared. In connection with labour market questions, a large number of institutional arrangements are relevant. Institutions bearing on the labour market include the framework for wage negotiations, legal protection against unjustified dismissal, conditions of work, vocational training and qualification, working hours, the mobility of labour, job matching process, early retirement, social protection of unemployed persons etc. Which arrangements should be compared with which other arrangements depends, of course, on the question under discussion and on the empirically determined relevance for that question of the institutions under review.

In order to carry out a comparison between countries it is often necessary to make the arrangements in the different countries comparable. This may require converting qualitative information into quantitative; it may require aggregating individual indicators into a comprehensive indicator. Weighting schemes based on cluster or on factor analysis can be helpful in this connection (Nicoletti et al. 1999). A concrete example for this kind of procedure is the compression of 22 individual indicators into one comprehensive indicator representing the effectiveness of the measures of protection against dismissal in individual countries (OECD 1999, p. 49ff.).

Comparisons limited to a point in time are often not sufficient to capture the difference between institutional arrangements. As a rule, such arrangements are initially introduced or later modified in the course of reform processes extending over longer periods of time. Furthermore, institutions only bring about behavioural changes and processes of 
adaptation affecting the real economy when they have been applied over a certain period of time. Therefore it is necessary to compare institutions in their development over time. But time series appropriate to this task are not always available.

One problem in carrying out international comparisons of institutions is that the texts of laws and edicts do not tell us whether they are actually applied or not. One country's strict rules may be paired with lax enforcement, whilst another country's lax provisions may be applied with great rigour. Simply comparing the text of the law would, in such cases, give a misleading picture. Let us take the application of sanctions for refusal of work by unemployed persons as an example. Out of the 12 OECD countries which provide for sanctions, Switzerland, Finland and Norway apply them relatively strictly; Japan, New Zealand, Belgium and Germany, on the other hand, apply them hardly at all (OECD 2000, p. 136). This example shows that evaluating the institutional arrangement without knowledge of its application is not satisfactory. But the information required for a well-founded evaluation is often not available.

International comparisons of institutions should not be limited to laws and administrative orders. The establishment of norms as well as the interpretation of legal or administrative provisions by the courts are in many cases of significance (Ichino et al. 2001). At the same time, attention must be paid to informal norms and customs, which are particularly important in lightly regulated countries. In the USA, for example, a high degree of external labour market flexibility resulting from scant protection against dismissal stands in contrast to a low degree of flexibility within the enterprise (Regini 2000, p. 23).

\section{Evaluation of Institutional Arrangements}

The international comparison of institutions should not stop at the mere collection of other countries' institutional arrangements, but should proceed to the identification of those arrangements which have brought about desirable results in the labour market. Those institutions that can contribute to the solution of specific problems in the researcher's own country have a claim to his special interest. The identification of appropriate institutional arrangements requires as a prior condition their evaluation. This procedure must be carried out in several steps: the objectives must be defined as a basis for measuring the effectiveness of the institutions; the intensity of compliance must be examined; the effectiveness of the arrangement must be estimated and a comprehensive cost-benefit analysis must be carried out (Schmid et al. 1996, p. 5).

Labour market institutions are created in order to attain certain results by means of modifications in the behaviour or in the expectations of the participants in the labour market. Correspondingly, the immediate objective can be to influence a certain behavioural or expectational aspect, e.g. the search activity of unemployed persons, the avoidance of free rider activities, or other behaviour (Teuling and Hartog 1998, p. 110 f.; Schmid and Schömann 1994, p. 50 f.). On the other hand, the goal pursued can refer to certain labour market results such as the position of the Beveridge curve, the equilibrium volume of unemployment, or real wage developments. From the objectives, 
performance indicators can be derived which can serve as a basis for assessing the institutional arrangements. Defining the objectives influences the evaluation results. Thus, empirical studies show that a high degree of protection against dismissal is an obstacle to reducing long-term unemployment; it is not clear, however, that such protection contributes to a higher rate of unemployment in general (Boeri et al. 2000, section 1.1.2).

The second step in evaluation refers to the implementation of the institutional arrangement. Arrangements which only exist on paper have scant effect. In order for them to have effect, they must be applied to the persons specified and the application must be long-term. In some cases, compliance must be enforced by means of sanctions. Implementation includes not only the concrete application, but also its harmonisation with complementary institutions and with discretionary economic policy measures; the behaviour of relevant actors must also be coordinated. As has been mentioned, the implementation of institutional arrangements is seldom documented. This is another obstacle to international comparisons of institutions (on the lack of information on the application of protection against dismissal in OECD countries, cf. Bertola et al. 1999).

The estimation of the effectiveness of institutional arrangements is affected by theoretical considerations. For quite a long time the neoclassical theory of the labour market was dominant and since it offered no room for the role of institutions, little or no attention was paid to their role in the labour market; in the last 15 to 20 years, however, such institutions have become increasingly an object of theoretical and empirical interest. Although a self-contained theoretical construction is still not available, there are a number of individual models which take institutional aspects into account (Blau and Kahn 1999; Nickell and Layard 1999).

The effects emanating from labour market institutions are complex. One reason for this is that there are influences coming from other determinants of economic activity such as the regulation of markets for goods, the financial incentives set by the state, the composition of the participants in the labour market, and their behavioural patterns. Then too, it must be borne in mind that the effects observed are quite possibly not pure effects, but only take place in connection with certain kinds of shocks (Blanchard 1998).

Different methods may be used to determine the effectiveness of labour market institutions:

- Aggregate analyses of effectiveness measure the influence of labour market institutions on certain macroeconomic indicators which are defined as the performance criteria. Example could be employment rates, unemployment rates, exits from unemployment, or the level of wages. Such analyses of effectiveness are carried out at the regional or national level. An advantage of this approach is that such indicators take into account both direct and indirect effects. A disadvantage is that although effective institutions can be identified, very little light is shed on the details of the most desirable institutional arrangement (Hagen and Steiner 2000, p. 75ff.). 
- The last mentioned disadvantage is less likely to attend microeconomic evaluation studies. Here the researcher attempts to estimate the effect of institutional arrangements on the market participant directly affected by means of individual data. The actual situation is compared to a counterfactual situation in which it is supposed that he or she were not affected. Of course, the same person cannot be at once affected and not affected. It is therefore necessary to form a control group, which ideally should differ from the group of persons affected only in one respect: the institutional arrangement under review does not affect them (Schmidt et al. 2001, p. 28ff.). Social experiments of this kind have been up till now carried out above all in North America, but not in Germany. In the framework of Canada's "Self-Sufficiency Project", which examined the programmes of reinsertion in employment among long term unemployed single parents in the provinces of British Columbia and New Brunswick, 6000 single parents were chosen at random, and divided into two groups, one half being assigned to the programme group, the other half to the control group Ochel 2002, p. 135). The evaluation was based on a comparison between the results obtained in the two groups. Microeconomic evaluation can also be based on data not obtained from experiments. This approach seeks to replace the missing control group with econometric and statistical procedures (Heckmann et al. 1999).

- Microeconomic evaluations capture the direct, but not the indirect effects. The indirect effects arise as a result of substitution and displacement effects. An example of a substitution effect would be the case of an employer responding to a change in relative wages by replacing his employees with previously unemployed persons, for whom the rules regarding the conditions on which they are obliged to accept employment have been tightened. It is possible to attempt to capture such substitution effects by surveying the employers, the employees and the unemployed persons concerned.

Analyses of effectiveness only provide information about the effects of institutional arrangements. The effects obtained must, however, be set in relation to the cost they entail. If all direct and indirect effects and costs have been taken into account, then in effect a comprehensive cost-benefit analysis has been carried out, which would form a basis for economic policy decisions.

\section{Analytical Comparisons of Aggregate Effects in an International Context}

If the institution under review shows no variation over time, then the meaningfulness of aggregate analysis of effects that refer to one country will be limited. In this case, a comparative evaluation across international boundaries is a possibility. One will look for countries in which the institution concerned has experienced changes. Thus it is possible to capture the effects of changes in trade union density by comparing the USA with Canada. In the USA the degree of organisation has been declining since the middle of the 1970s, whilst in Canada it has remained approximately constant. Then again, it may be useful to compare countries in which the institution of interest has always had a 
different weight or relative importance. Thus the effects of a greater coverage of wage agreements in Germany can be evaluated by means of comparisons with Denmark, Norway or Canada, where the coverage is more restricted.

Alongside comparisons between pairs of countries, multiple comparisons have gained in importance. Here, the effects of one or more institutional arrangements in different countries are analysed. Such studies may be based on cross section analysis, i.e. the differences in the institutional arrangements at a given time are compared with respect to their effects. Or the cross sectional data are combined with time series, in order to observe the changes in the institutional arrangements in the course of time.

Analyses of aggregate effects of institutional arrangements based on panel data, i.e. on cross section data combined with time series data have gained in importance throughout the 1990s. With this approach one has sought an answer to the question why unemployment in Europe has been increasing since the 1970s, whilst it has been receding in the USA. In this connection, the extent to which institutions are responsible for this cleavage has been examined. If institutional arrangements in Europe are detrimental to employment, US American arrangements on the other hand are shown to be favourable, then this would offer at least a partial explanation for the observed phenomenon.

Explaining the increase in unemployment in Europe exclusively with institutional changes has been challenged with the counter argument that many labour market institutions have remained unchanged since the 1960s. Hence, it is argued, institutional differences might explain at the most the difference in the magnitude of unemployment at a given time, but not the changes over time. In order to explain the differences in the development of unemployment in Europe and the USA, one ought not to study changes in institutions, but rather the ability of institutions to deal with macroeconomic shocks should be the principal focus. American institutions, it is maintained, are better able set in motion processes of adaptation to demand, productivity, wage and interest rate shocks than European regulatory approaches (Blanchard and Wolfers 2000, p. C2).

Analytical comparisons of aggregate effects in an international context have up till the present been carried out primarily by OECD staff (Scarpetta 1996; Elmeskov et al. 1998 and others) as well as by university researchers. A representative picture of the available panel analyses relating to the labour market provide: Layard et al. 1991, especially chapter 9; Blanchard and Wolfers 2000; Fitoussi et al. 2000; Belot and van Ours 2000; Nickell and Layard 1999; and Nickell et al. 2001. All studies take into consideration both institutions and shocks as determinants of unemployment, but proceed on different concepts of the functional interrelationships. For Layard, Blanchard and Fitoussi, either shocks or long-term changes in real economic variables are the basic causes of unemployment. The extent and the duration of the effects resulting from shocks are influenced by institutional differences in the different countries. Belot and Nickell, on the other hand, see changes in institutional arrangements as being primarily responsible for the increase in unemployment in Europe. Whilst Belot takes into account interaction between the institutions, Nickell excludes very largely this aspect. 
In the following paragraphs the results of the analyses of Blanchard and Wolfers (2000) and of Nickell and Layard (1999) are presented briefly. Blanchard and Wolfers examine the increase in unemployment in Europe since the 1960s, which, however, developed differently in the individual countries. The authors come to the conclusion that longterm changes in total factor productivity, the real rate of interest and the demand for labour (as a result of the relative increase in the dearness of labour) explain the increase in average unemployment, but not the national differences. The differences observed between countries are rather due to the differences in the development of national labour market institutions. Only when the interaction between shocks and labour market institutions is taken into account, is it possible to explain the pattern of European unemployment.

Nickell and Layard (1999) examine the effects that changes in labour market institutions have on short-term, on long-term and on total unemployment (and on labour force participation). Besides the burden of taxes on wage and salary income, and the proportion of home owners (considered as a barrier to mobility). they also take into account the following institutional factors: protection against unjustified dismissal; trade union density; coverage of collective wage agreements; coordination of wage negotiations; extent to which unemployment benefits replace wages; duration of such benefits; active labour market policies. The study examines 20 OECD countries for two periods, viz. the average of $1983-88$, and $1989-94$. The authors conclude that the increase in unemployment was mainly due to the following factors:

- an increase in the burden of taxation of wage and salary income;

- high union density and high coverage of wage agreements; a coordination of wage negotiations between trade unions and employers associations (in some instances with the support of the state) can, however, considerably weaken the undesirable effect on unemployment;

- high and increasing replacement rate in case of unemployment, and especially a long duration of benefits.

Active labour market policy tends to reduce unemployment. Rigorous protection against dismissal increases long-term unemployment, reduces at the same time short-term unemployment and has practically no effect on overall unemployment. 
Table: Factors Explaining Unemployment ${ }^{\text {a }}$

\begin{tabular}{|l|rc|rr|rr|}
\hline Independent variable & \multicolumn{2}{|c|}{$\begin{array}{c}\text { Total } \\
\text { unemployment }\end{array}$} & $\begin{array}{c}\text { Long-term } \\
\text { unemployment }\end{array}$ & $\begin{array}{c}\text { Short-term } \\
\text { unemployment }\end{array}$ \\
\hline Total Tax Wedge (\%) & 0.027 & $(4.0)$ & 0.023 & $(1.6)$ & 0.028 & $(3.5)$ \\
Employment Protection (1-20) & & & 0.052 & $(1.4)$ & -0.061 & $(2.8)$ \\
Union Density (\%) & 0.010 & $(2.3)$ & 0.010 & $(1.0)$ & 0.0031 & $(0.5)$ \\
Union Coverage Index (1-3) & 0.38 & $(2.7)$ & 0.83 & $(2.3)$ & 0.45 & $(2.1)$ \\
Coordination (Union + Employer) & -0.43 & $(6.1)$ & -0.54 & $(3.6)$ & -0.34 & $(3.8)$ \\
(2-6) & & & & & & \\
Replacement Rate (\%) & 0.013 & $(3.4)$ & 0.011 & $(1.3)$ & 0.013 & $(2.6)$ \\
Benefit Duration (years) & 0.10 & $(2.2)$ & 0.25 & $(2.7)$ & 0.045 & $(0.8)$ \\
Active Labour Market Policies & -0.023 & $(3.3)$ & -0.039 & $(2.8)$ & -0.097 & $(1.2)$ \\
Owner Occupation Rate (\%) & 0.013 & $(2.6)$ & -0.0007 & $(0.1)$ & 0.01 & $(2.7)$ \\
Change in Inflation (\% pts. p.a.) & -0.21 & $(2.2)$ & -0.30 & $(1.6)$ & -0.29 & $(2.7)$ \\
Dummy for 1989 - 1994 & 0.15 & $(1.5)$ & 0.30 & $(1.8)$ & 0.092 & $(1.0)$ \\
$\mathrm{R}^{2}$ & 0.82 & & 0.84 & & 0.73 & \\
N [countries. periods] & 40 & {$[20.2]$} & 38 & {$[19.2]$} & 38 & {$[19.2]$} \\
\hline a Results of regression analysis, t-statistics in rounded parentheses. & & & \\
\hline
\end{tabular}

Source: Nickell. S. J. and R. Layard (1999), p. 3053.

Analytical comparisons of aggregate effects in an international context make an important contribution to the explanation of unemployment (as well as to explaining the evolution of other macroeconomic indicators). They identify the institutional arrangements (or to be more precise: the changes in institutional arrangements) which bring about an increase, and those which bring about a decrease in unemployment. Such studies capture the overall effect of regulations; they cannot, however, separate out the direct and indirect effects. Long-term analyses of effects that examine periods extending over several decades make it possible to abstract from short-term institutional variations.

Analyses of aggregate effects have, however, their limitations. Quite aside from the difficulties involved in dealing with certain methodological problems such as endogenous effects or interdependence between institutions, such analyses are accompanied by loss of information. Peculiarities of individual countries are lost sight of, specific regional contexts are passed over. The details of institutional arrangements in the individual countries are for the most part ignored. Such analyses do not take into account the degree to which regulations are applied or the conditions of their 
implementation. Above and beyond the loss of information, these analyses do not always show what motivated the measures taken to obtain the effects, nor do they deal with the role that market participants' expectations play in connection with the efficiency of institutions. And finally, analyses of aggregate effects do not allow conclusions about the attainment of the objectives of specific groups (Boeri et al. 2000, Section 5; Hagen and Steiner 2000; Schmid 2001, p. 106f.).

Analyses of aggregate effects provide valuable indications on how to change labour market institutions in order to attain certain objectives. But they are insufficient as a basis for formulating concrete reform measures. They must be complemented by microeconomic evaluation studies. These studies must take cognisance of the way certain institutional arrangements are designed and applied in the countries being compared and they must make this a part of the assessment. Furthermore, the question of transferring institutional arrangements from one country to another must be considered.

\section{Microeconomic Evaluation Which Takes into Account Complementarities}

Whilst analyses of aggregate effects must up to a certain point abstract from the peculiarities of institutional arrangements, microeconomic evaluation can focus on the characteristics of individual regulatory arrangements. Such evaluation attempts to capture the historical origins of an institution, the specific form it has taken and the way it is applied. Moreover, the environment in which the arrangement operates must be taken into account. In order to comply with these requirements, microeconomic analyses are primarily carried out for regions of countries or countries.

At the core of a microeconomic evaluation lies the assessment of the effects which the institutional arrangement has on those directly affected. The effects are measured on the basis of individual data. A typical object of such an evaluation is for example the connection between sharpening the eligibility requirements for receiving unemployment benefits on the one hand, and the number of departures from and accessions to the population of recipients on the other. For example, this relationship can be examined based on Danish experience, where changes in the system were undertaken. Since 1996, young people under 25 who have not completed professional or vocational training and who in the preceding nine months have been unemployed for at least six, are offered an 18 month training opportunity. Rejecting this offer entails the loss of unemployment benefits. The benefits paid during the duration of the training are clearly lower than the unemployment benefits. In this way, one hopes to create an incentive to take up regular professional or vocational training, or to take up a job, before the training programme is finished. In addition, one hopes to limit participation to those young people who do not have the possibility to participate in regular training. The experience has been that once this training programme was started, there was an increase in departures from the group of unemployed young people in favour of participation in regular professional or vocational training. Furthermore, after the training programme had been in operation for approximately three months, the number of unemployed young people renouncing their entitlements increased sharply. It is clear that the sanctions imposed on persons who 
refuse their participation, which entailed the loss of their entitlement to unemployment benefits, were having an effect (Jensen et al. 1999).

In evaluating the effects of changes in a system of regulation certain methodological requirements have to be complied with. This can be illustrated with the Danish study just mentioned. The system of sanctions applied to unemployed young people cannot be adequately evaluated by only examining the behaviour of this group of young people. It is possible that they would have sought regular professional or vocational training, or would have taken up employment, without any sanctions being imposed. Hence it is necessary to compare the behaviour of unemployed young people subject to these sanctions to the behaviour of unemployed young people not subject to these penalties. At the same time, the groups being compared should be as similar as possible with respect to all characteristics bearing on the success of the measure taken, in order to avoid a selective bias (Hagen and Steiner 2000, p. 44 ff.; Schmidt 2000).

But observations made at the microeconomic level do not permit conclusions about effects at the macroeconomic level. This is due to the presence of indirect affects (substitution and displacement effects) which cannot be captured by a purely microeconomic evaluation. Thus, to continue with the Danish example, rigorous sanctions may lead to unemployed young people accepting low paid jobs. Employers might take advantage of this situation in order to replace some of their employees with formerly unemployed persons (substitution affect). If this is the case, then the macroeconomic effect on employment will be overstated, since only regular employment obtained by those who were previously unemployed is taken into account, whilst the loss of jobs by those who were previously employed is neglected. The indirect effects can be quantified approximately by carrying out surveys among employees and employers. Such surveys are a useful supplement to microeconomic evaluations.

The isolated evaluation of an individual institutional arrangement provides information of only limited value, since it does not take into account the complementary relationships between this intervention in the labour market and other regulations. Complementarities are to be found wherever the effects of one particular institutional arrangement depend on the simultaneous application of other arrangements (Orszag and Snower 1999, p. 3). Interrelationships between institutional arrangements are frequent. Thus protection against unjustified dismissal will have the effect that employers will be reluctant to hire new employees; and this reluctance will be all the greater, the more unemployed persons limit their search activity owing to generous unemployment benefits. The effects of protection against dismissal also depend on the way wages are determined. To the extent that employed persons ("Insiders") have bargaining power in wage negotiations, and to the extent that their bargaining position is further strengthened by protection against the loss of their jobs, then wage and salary increases will be greater, with the result that there will be fewer hirings. If, on the other hand, wages and salaries are determined in a framework in which neither side has significant bargaining power, then it is conceivable that the costs of rigorous protection against dismissal are compensated for by the lower wage and salary level, with the result that 
the hiring behaviour of employers is not much affected (Coe and Snower 1996; Eichhorst et al. 2001, p. 166).

The presence of complementarities between the different attempts to regulate the labour market and the market for goods on the one hand, and between the regulatory measures and other discretionary measures of economic policy, on the other, has far-reaching consequences for the formulation of employment policy. Partial reforms of the institutional arrangements which do not take into account these complementary relationships often have only slight success. A comprehensive employment policy approach which takes into consideration the complementarities between institutional arrangements and other measures and which therefore mobilises more resources is likely to be more successful (Orszag and Snower 1999, p. 22). But on the other hand, such a comprehensive approach presents more imponderabilities than a partial approach and is more likely to meet with the opposition of interest groups (cf. section 11).

The comparative evaluation of microeconomic country studies provides insights into the institutional arrangements and measures with which employment effects can be attained in the most effective way. Comparative evaluations across international boundaries have been carried out for example by the Bertelsmann Foundation in the context of its international reform monitor programme; these studies have focussed on social policies, labour market policies and wage and salary policy. Hagen and Steiner (2000), Martin (2000), Schmid (2001), and Schmidt et al. (2001) have published studies in this area as well. In addition, such comparative studies provide insights on the optimal design of individual institutional arrangements as expressed in the concept of "Best practices".

\section{International Transfer of Institutions Under Conditions of Competition Between Systems}

Institutional learning is one of the most important conditions for institutional transfer between countries. In the case of state regulatory activities, the only way such a transfer could occur would be through the conscious decision by the government to adapt another country's arrangements. The decision will depend to a great degree on whether the government concerned is that of a country enjoying a considerable measure of autonomy, or that of a country subject to system competition.

The government of a country enjoying a high degree of autonomy in its decisions will as a rational actor give precedence to the wishes of its citizens. If an increase in employment is high on their scale of priorities, then the government will decide on measures tending to increase employment. If, on the other hand, the citizens attach more importance to distributional goals, then the decisions will tend to favour arrangements for redistribution. The preference for a given objective does not mean that a particular foreign institutional arrangement must be adapted. This would only be the case if with respect to this objective there were a clearly superior institutional set-up. But there is no evidence for this. On the one hand there is the "one best way" thesis, on the other hand, the thesis of the functional equivalence of institutional networks. In this view, a given 
economic policy objective can be equally well attained within different institutional systems. In support of the thesis of functional equivalence it is pointed out that in both a welfare state such as Sweden and a liberal economic system such the United States of America it is possible to attain nearly full employment. The success of the Netherlands' "polder model" also supports the functional equivalence thesis, although in all cases the sustainability of the success attained must be subject to scrutiny.

In contrast to an economy which is for the most part closed, governments of open economies which are subject to system competition must take into account not only the preferences of their citizens, but also the effects of their policies on the locational decisions of the mobile factors of production. Owing to increased mobility, enterprises and labour can change their location more easily than in the past. This is particularly true of enterprises, and governments have to be particularly solicitous of their interests. Since almost all governments have to consider the effects of their decisions on the behaviour of the mobile factors of production, they are all subject to international locational competition.

This competition to be an attractive location for economic activity affects many areas of government policy, including that area bearing on the legal and institutional framework of the labour market. This framework comprehends the system of wage and salary determination, the system of social security, the system of education and vocational training, the institutional system of private households (Schütz et al. 1998, p.16). The content of arrangements and the way they are applied are important influences in the locational decisions of enterprises and the mobility decisions of employees. It is not always clear whether changes in the institutional arrangements affect enterprises' locational decisions favourably or unfavourably. For example, cuts in the system of social security may on the one hand provide relief from taxes and social security contributions for enterprises, but on the other hand, social harmony may be endangered, and productivity may as a result suffer. In the same way, limitations on the protection against dismissal enjoyed by employees may increase the flexibility of employers in their personnel decisions, but it may also discourage employees from developing human capital specific to the enterprise where they work Sachverständigenrat (Council of Economic Experts) 1997, Paragraph 306 ff.).

In view of the international competition between systems the question arises whether existing differences between countries will endure, or whether individual countries will be forced to adapt their own system of institutions to the most efficient model. If this last alternative prevails, then a process of convergence of institutional systems will be observed. Although it is clearly the case that the competition between systems obliges countries to adapt their network of institutions to continually changing exigencies, in order to avoid falling behind in the competition for locational advantage, nonetheless there are a number of reasons to believe that a convergence of institutional systems will not come about.

For one thing, the competition for locational advantage does not affect all areas of the economy. Whilst large parts of manufacturing industry are subject to international competition, this is not true to the same extent for the service sectors of the economy. 
At the same time, not all factors of production show the same degree of mobility, so that the exit option is not equally available to all.

Moreover, the theory of comparative institutional advantage provides arguments in favour of a multiplicity of institutional systems. If the international division of labour leads individual countries to specialise in certain products, then this will be associated with the simultaneous specialisation in certain institutional networks. The deregulated labour markets and dynamic markets for venture capital that are characteristic of the USA, for example, provide advantages for enterprises that are engaged in radical innovations such as the development of entirely novel products or new production processes. In order to carry out such innovations successfully it is necessary that one should be able to hire and sack employees quickly, establish new enterprises easily etc. Under such circumstances enterprises in sectors such as biotechnology, software development, microelectronic, and entertainment find an environment in which they can prosper. In Germany, on the other hand, labour law has evolved offering job security, on the job training, industrial democracy etc. The German system of corporate governance provides enterprise with a long-term planning horizon. These institutional arrangements are favourable to incremental innovation in the form of continual improvements in products and in processes in small steps. These kinds of innovations provide competitive advantages to producers of machines, motor vehicles, durable consumers goods etc. (Hall and Soskice 2001).

The convergence of institutional arrangements as a result of system competition would mean that the government would, as a rule, be responding to the needs for reform articulated by enterprises. If the political decision making process is oriented to other interests such as those expressed by voters, or if it is autonomous, then convergence is less likely to occur.

And finally, it should be pointed out that there is little empirical evidence for the convergence thesis. The network of labour market institutions in highly developed industrialised countries shows quite considerable differences, as can be seen if one compares the system of wage negotiations in continental European countries with those in the Anglo-Saxon countries. The divergences have, indeed, rather increased. Whilst the continental European countries during the last 40 years have scarcely deregulated their systems of wage negotiations, the Anglo-Saxon countries have pushed forward their efforts to liberalise their systems (Nickell et al. 2002; Traxler et al. 2001). In Margaret Thatcher's Great Britain and in New Zealand, in 1991, best practice models taken from the United States were introduced as part of a thorough overhaul and reform of labour market institutions.

Competition between systems results - as has been shown - in the reaction of mobile production factors being taken into account in addition to the preferences of citizens when systems of institutions are designed. This competition can be functional in the sense that it contributes to improvements of the institutional arrangements that have been introduced with efficiency or distributional objectives (cf. section 4). But it can also be dysfunctional, i.e. it can lead to arrangements that do not produce the desired results. This can be illustrated based on the example of the social security system. In an 
open economy in which it is possible to change one's country of residence, people who represent a good risk from the standpoint of social policy (i.e. they are unlikely to make use of welfare entitlements) are likely to move away from the welfare state, whilst people who represent a poor risk (i.e. the likelihood that they will at some point seek to take advantage of social protection is high) will try to move to the state offering the most comprehensive protection. This factor mobility results in financial burdens for the welfare state. In order to reduce factor migration, the welfare state will lower the burden of taxes or contributions for the net contributors to the system, and lower the entitlements for those who are net recipients of benefits. This may be reinforced by the reactions of other countries and the final result will then be an erosion of the system of social security. A redistributional policy represented by the setting-up of a system of social security, which from the point of view of the individual country might be Paretoefficient, will be affected to its detriment by such influences, unless countermeasures are taken (Sinn 1997; Sinn 2002).

\section{Path Dependency and Institutional Inflexibility}

The competition between systems which is part of the globalisation process has increased the pressure to reform the institutional arrangements whilst at the same time taking into account the reactions of mobile factors of production; here it has proved to be necessary to consider the experiences gained in other countries. In view of this new challenge, the question arises to what extent national systems of institutions are capable of being modified? Is it only possible to transfer foreign institutional arrangements when they are compatible with existing values and with the existing network of institutions in the target country? Under what conditions will the interaction between the foreign institutions and the traditional set of rules be seriously disturbed (problem of institutional coherence)? To what extent will the institutional transfer make excessive demands on the procedural competence of the recipient country?

In responding to these questions the thesis of the path dependency of institutional development has gained recognition. The thesis is that institutional change at home is only influenced to a slight degree, if at all, by the perception of the evolution of foreign institutions; all attempts to learn from foreign countries, and especially all attempts to implement what has been learned, can only be successful if carried out in the context of existing institutions (Scherrer 2001, p. 1). Disturbances of institutional compatibility give rise to considerable costs, so that path dependency is associated with considerable institutional inflexibility.

On what notion of path dependency are these ideas based? According to Ackermann (2001, p. 55) path dependency is present if the process of institutional development has more than one result, and if the result finally reached depends on the preceding path of development. A state of institutional development that has been attained tends to be self reinforcing and hence a considerable measure of institutional inflexibility is the result (Arthur 1994). It is difficult to adapt institutional arrangements to changed conditions. Therefore, there is little scope for transferring successful arrangements from foreign countries. 
The inflexibility of paths of institutional development is due to positive feedbacks. Following David (1994), Ackermann (2001, chapter 3) distinguishes between three causes of positive feedbacks in institutions. They refer to the level of actions of interacting individuals, to the level of rules which structure these interactions, and to the interrelationship between the levels of actions and rules. On the action level, coordination effects arise as a result of the advantages offered by standardised patterns of behaviour. These can lead to stable rules. At the level of rules, complementary effects will arise, if the interdependent relationships between institutions are of a complementary nature, i.e. if following a particular rule becomes more attractive as a result of the interdependence with other rules. Positive feedback as a result of interactions between the levels of societal rules and the level of individual behaviour, finally, result in processes of social communication in a society which lead to the convergence in its members' mental structures.

In the concept of path dependency, the feed-back effects are responsible for the fact that the path of institutional development imposes narrow limits on the scope for institutional modifications. For this reason suboptimal institutions are retained. The legacy of existing institutions also sets very narrow limits to the possibilities of institutional transfer across international boundaries. The path of institutional development is only departed from when the actors consider the loss of efficiency to be greater than the costs associated with the creation of new and efficient institutions (North 1992).

A number of objections to the thesis of path dependence and institutional inflexibility may be formulated. It does not seem very plausible to glimpse in the past development of institutions only a limiting force, but not at the same time a source of experience which can be useful in carrying out the reform of institutions. At the same time it is not at all clear that a path consists only of self-reinforcing sequences and that counterreactions are inconceivable. A further central deficiency of the notion of path dependency is that it is difficult to operationalise. What is the relevant period of time for the path? Which institutions are decisive for the path? Which events which may have influenced the path should be taken into consideration (Scherrer 2001)?

Despite these points of criticism, the empirical evidence is not entirely hostile to the idea of path dependency. The inertial energy with which many west European countries cling to their labour market institutions seems to be related to the inflexibility predicted by the thesis of path dependence. However, with respect to labour market institutions in highly developed economies it is not possible to speak of complete inflexibility. Great Britain and New Zealand are not the only countries to have carried out successfully reforms of their labour market institutions; other countries such as the Netherlands and Denmark have also made such reforms. What is more, the process of institutional learning has gained in importance in the last decades. And then the question arises whether the inertia observed in many countries is really due to path dependence, or whether other factors such as the resistance of powerful interest groups is not responsible. 


\section{The Political Economy of Institutional Transfer}

The theory of path dependence refers to spontaneous development processes which are not the result of contests of power. If such processes only offer a partial explanation for the inflexibility of institutions and thus for the limits to institutional transfer, then the question arises whether the power of the state and the influence exerted by interest groups are not the principal factors hindering the international transfer of institutions? Relationships of power can play a role in connection with perceiving and selecting advantageous institutional arrangements, in persuading socially relevant groups at home that particular arrangements are advantageous, and in introducing and applying such arrangements.

According to Scherrer (2001), even the perception of the advantageousness of institutions is tied to interests. In the national discourse on institutional reform, only those institutions or arrangements which are deemed compatible with the interests of the elites and the influential interest groups are admitted to the debate. The ability of central actors in society to convince others of the advantages of foreign arrangements depends among other things on whether they succeed in presenting the economic problems under discussion as being so threatening, that they can only be dealt with successfully by adapting foreign institutions, which are presented as having coped successfully with the problem. This ability will be all the greater, the more influence these central actors have in the process of opinion formation.

If power relationships and competing interests play an important role in determining the content of the national discourse on foreign institutional models, they play an even more decisive role in the decisions concerning the introduction and the implementation of institutional arrangements. Labour market institutions are primarily at the service of redistributive objectives. If institutional reforms are undertaken with the objective of improving efficiency, then resistance can be expected from those who expect to lose out. If the losers constitute power interest groups, then the reforms will be prevented.

Resistance to the adaptation of foreign labour market regulations can have different causes:

- The number of losers is larger than the number of winners. Thus, for example, the liberalisation of the protection against unfair dismissal will mean that for many insiders the risk of losing their job increases; but the chance of finding employment will only increase for a relative small number of unemployed persons.

- The number of losers resulting from a reform of the labour market may be small, but the much larger number of winners are scattered among many heterogeneous groups which aside from labour market issues have different interests, so that they are unable or unwilling to agree on a common strategy to push through the reform. In such a case the losers may be successful in their resistance. 
- There is uncertainty about the effects of the reform. A large number of those that will be affected are risk adverse and unable to form an opinion whether they will in the end be among the losers; they therefore argue in favour of retaining the status quo.

- To the extent that the reform brings about improvements in efficiency, compensatory payments may make winners out of potential losers. But the potential losers are afraid that the compensation will not be high enough, or will be reduced in future, and therefore withhold their approval (Alogoskoufis et al. 1995, chap. 6; Saint-Paul 2000).

\section{Summary}

The international comparison of institutions has become more important. It is an instrument with which the political decision makers in a country seek to learn from other countries and in this way to improve the quality of decisions taken. The learning process is not confined simply to finding out what the institutional arrangements of foreign countries are, but also examines the effectiveness of these arrangements. Analyses of aggregate effects of institutional arrangements measure the influence of labour market institutions on certain indicators of success that are defined macroeconomically. They inform us which arrangements have led internationally to an increase, and which to a reduction in unemployment. Microeconomic evaluations, on the other hand, focus on individual regulatory efforts and estimate their effects on those directly affected. By comparative analysis of microeconomic evaluations, insights into the best design for individual regulations (best practices) may be obtained.

In adapting institutional arrangements that seem to promise success, national governments should take into account the complementary relationships existing between institutional arrangements. Under certain circumstances, comprehensive institutional reforms may be called for. However, different factors limit the scope for such reforms. System competition forces governments to take into account the effects of their decisions on the locational choices of mobile factors of production. Furthermore, the inflexibility of their own institutional arrangements and values arising from path dependency makes the adaptation of foreign institutional arrangements more difficult. And finally, powerful interest groups at home may be opposed to the transfer of institutions, or may seek to influence the content of such a transfer. The combined effects of all of these factors, which are different from one country to another, leads to the multiplicity of institutional systems which characterises today's international scene (Freeman 2000). 


\section{References}

Ackermann, R. (2001), Pfadabhängigkeit, Institutionen and Regelreform, Tübingen.

Addison, J. T. and W. St. Siebert (1999), Regulating European Labour Markets: More Costs than Benefits?, London.

Agell, J. (2000), On the Determinants of Labour Market Institutions: Rent-sharing vs. Social Insurance, CESifo Working Paper No. 384.

Alogoskoufis, G., C. Bean, G. Bertola, D. Cohen, J. Dolado and G. Saint-Paul (1995), Unemployment: Choices for Europe, London.

Arthur, W. B. (1994), Increasing Returns and Path Dependence in the Economy, Ann Arbor.

Bamber, G. J. and R. D. Lansbury (1998), “An Introduction to International and Comparative Employment Relations" in: G. J. Bamber and R. D. Lansbury (eds.), International and Comparative Employment Relations, London, Thousand Oaks and New Delhi, pp. 1 - 33.

Belot, M. and J. C. van Ours (2000), "Does the Recent Success of some OECD Countries in Lowering their Unemployment Rates Lie in the Clever Design of their Labour Market Reforms?", IZA Discussion Paper No. 147.

Bertola, G., T. Boeri and S. Cazes (1999), "Employment Protection and Labour Market Adjustment in OECD Countries: Evolving Institutions and Variable Enforcement", ILO Employment and Training Papers No. 48. Geneva.

Blanchard, O. (1998), "Thinking about Unemployment", Paolo Baffi Lecture on Money and Finance, 16 October 1998, Rome.

Blanchard, O. and J. Wolfers (2000), "The Role of Shocks and Institutions in the Rise of European Unemployment: The Aggregate Evidence", The Economic Journal (Conference Papers) 110, pp. C 1 - C 33.

Blau, F. D. and L. M. Kahn (1999), "Institutions and Laws in the Labor Market", in: O. Ashenfelter and D. Card (eds.), Handbook of Labor Economics, Vol. 3, pp. 1399 - 1461.

Boeri, T., G. Nicoletti and S. Scarpetta (2000), "Regulation and Labour Market Performance", CEPR Discussion Paper No. 2420.

Coe, D. T. and D. J. Snower (1996), "Policy Complementarities: The Case of Fundamental Labor Market Reform" IMF Working Paper No. 93.

Cox, R. H. (1999), "Ideas, Policy Borrowing and Welfare Reform", in: R. H. Cox and J. Schmid (eds.), Reformen in westeuropäischen Wohlfahrtsstaaten - Potentiale und Trends, Tübingen. pp. $14-27$.

David, P. A. (1994), "Why are Institutions the 'Carrier of History'? Path Dependence and the Evolution of Conventions. Organisations and Institutions", Structural Change and Economic Dynamics 5 (2), pp. 205 - 220. 
Dolowitz, D. P. and D. Marsh (2000), „Learning from Abroad: The Role of Policy Transfer in Contemporary Policy-Making“, Governance: An International Journal of Policy and Administration, Vol. 13, No. 1, January. pp. 5 - 24.

Eichhorst, W., St. Profit and E. Thode (2001), Benchmarking Deutschland: Arbeitsmarkt und Beschäftigung. Bericht der Arbeitsgruppe Benchmarking und der Bertelsmann Stiftung, Berlin, Heidelberg.

Elmeskov, J., J. P. Martin and S. Scarpetta (1998), "Key Lessons of Labour Market Reforms: Evidence from OECD Countries' Experience”, Swedish Economic Policy Review,. Vol.5 . No. 2, pp. $205-252$.

Esping-Andersen, G, (1996). "After the Golden Age? Welfare State Dilemmas in a Global Economy”,. in: G. Esping-Andersen (ed.), Welfare States in Transition. National Adaptations in Global Economies, London. Thousand Oaks, New Delhi, pp. $1-31$.

Fitoussi, J. P., D. Jestaz, E. S. Phelps and G. Zoega (2000), "Roots on the Recent Recoveries: Labor Reforms or Private Sector Forces?", Brookings Papers on Economic Activity 1, pp. 237 291.

Freeman, R. B. (1995), "The Large Welfare State as a System”, AEA Papers and Proceedings, Vol. 85, No. 2. May, pp. $16-21$.

Freeman, R. B. (2000), "Single Peaked vs. Diversified Capitalism: The Relation Between Economic Institutions and Outcomes", NBER Working Paper 7556.

Hagen, Th. and V. Steiner (2000), Von der Finanzierung der Arbeitslosigkeit zur Förderung von Arbeit, Analysen und Handlungsempfehlungen zur Arbeitsmarktpolitik, Schriftenreihe des ZEW, Vol. 51, Baden-Baden.

Hall, P. A. and D. Soskice (2001), “An Introduction to Varieties of Capitalism”, in: P. A. Hall and D. Soskice (eds.), Varieties of Capitalism, The Institutional Foundation of Comparative Advantage, Oxford, pp. $1-68$.

Heckman, J. J., R. J. LaLonde and J. A. Smith (1999), "The Economics and Econometrics of Active Labour Market Programs", in: O. Ashenfelter and D. Card (eds.), Handbook of Labor Economics, Vol. 3 a, pp. 1865 - 2097.

Ichino, A., M. Polo and E. Rettore (2001), “Are Judges Biased by Labour Market Conditions? The Selection of Firing Litigations for Trial in an Italian Firm", CEPR Discussion Paper 2804.

Jensen, P., M. S. Nielsen and M. Rosholm (1999), The Effects of Benefits, Incentives and Sanctions on Youth Unemployment, Center of Labour Market and Social Research, Working Paper No. 99-05.

Layard, R., S. J. Nickell and R. Jackman (1991), Unemployment: Macroeconomic Performance and the Labour Market, Oxford.

Martin, J. P. (2000), "What Works among Active Labour Market Policies: Evidence from OECD Countries' Experiences”, OECD Economic Studies No. 30, I, pp. 79 - 113. 
Nickell, St. and R. Layard (1999), "Labour Market Institutions and Economic Performance", in: O. Ashenfelter and D. Card (eds.), Handbook of Labor Economics, Vol. 3 (3C), pp. 3029 3084.

Nickell, St., L. Nunziata, W. Ochel and G. Quintini (2001), "The Beveridge Curve, Unemployment and Wages in the OECD from the 1960s to the 1990s", Centre for Economic Performance Discussion Paper No. 502.

Nicoletti, G., S. Scarpetta and O. Boylaud (1999), "Summary Indicators of Product Market Regulation with an Extension to Employment Protection Legislation”, OECD Economics Department Working Paper No. 226.

North, D. C. (1992). Institutionen, institutioneller Wandel und Wirtschaftsleistung, Tübingen.

Ochel, W. (2002), "Finanzielle Arbeitsanreize - Konzeptionen und Ergebnisse in

Großbritannien, Irland und Kanada", in: S. Dann, A. Kirchmann, A. Spermann and J. Volkert (eds.), Kombi-Einkommen - Ein Weg aus der Sozialhilfe?, Baden-Baden, pp. 120 - 140.

OECD (1999): Employment Outlook, Paris.

OECD (2000): Employment Outlook, Paris.

Orszag, J. M. and D. J. Snower (1999), “Anatomy of Policy Complementarities”, IZA Discussion Paper No. 41.

Regini, M. (2000), “The Dilemmas of Labour Market Regulation”, in: G.Esping-Andersen and M. Regini (eds.), Why Deregulate Labour Markets?, Oxford, New York, pp. 11 - 29.

Sachverständigenrat zur Begutachtung der gesamtwirtschaftlichen Entwicklung (1997), Jahresgutachten 1997/98, Stuttgart.

Saint-Paul, G. (2000), The Political Economy of Labour Market Institutions, Oxford.

Scarpetta, S. (1996), "Assessing the Role of Labour Market Policies and Institutional Settings on Unemployment: A Cross-Country-Study”, OECD Economic Studies No. 26 (1). pp. 43 - 98.

Scherrer, Ch. (2001), Jenseits von Pfadabhängigkeit und "natürlicher Auslese":

Institutionentransfer aus diskursanalytischer Perspektive, Berlin.

Schmid G. and K. Schömann (1994), "Institutional Choice and Flexible Coordination: A Socioeconomic Evaluation of Labor Market Policy in Europe", in: G. Schmid (ed.), Labour Market Institutions in Europe, Armonk and London, pp. 9 - 57.

Schmid, G. (2001), "Internationale Erfahrungen mit Maßnahmen der Arbeitsmarktpolitik", in: V. Steiner and H. Wolff (eds.), Mismatch am Arbeitsmarkt - was leistet die Arbeitsmarktpolitik, Münster, New York, Munich, Berlin, pp. 91 - 142.

Schmid, G., J. O'Reilly and K. Schömann (1996), ,Theory and Methodology of Labour Market Policy and Evaluation: An Introduction”, in: G. Schmid, J. O'Reilly and K. Schömann (eds.), International Handbook of Labour Market Policy and Evaluation, Cheltenham and Brookfield, pp. $1-33$. 
Schmidt, Ch. M., K. F. Zimmermann. M. Fertig and J. Kluve (2001), Perspektiven der Arbeitsmarktpolitik, Internationaler Vergleich und Empfehlungen für Deutschland, Berlin, Heidelberg.

Schmidt, Ch. M. (2000), “Arbeitsmarktpolitische Maßnahmen und ihre Evaluierung: Eine Bestandsaufnahme”, DIW Vierteljahreshefte zur Wirtschaftsforschung 69, pp. 425 - 437.

Schütz, H., S. Speckesser and G. Schmid (1998), Benchmarking Labour Market Performance and Labour Market Policies: Theoretical Foundations and Applications, Discussion Paper FS I 98 - 205. Wissenschaftszentrum Berlin für Sozialforschung, Berlin.

Sinn, H.-W. (1997), "Das Selektionsprinzip und der Systemwettbewerb”, in: A. Oberhauser (ed.), Fiskalföderalismus in Europa, Berlin, pp. 9 - 60.

Sinn, H.-W. (2002), The New Systems Competition. Yrjö Jahnsson Lectures 1999, Oxford and Malden, Mass. (forthcoming).

Stigler, G. (1946), “The Economics of Minimum Wage Legislation”, American Economic Review, Vol. 36, pp. $358-65$.

Strassheim, H. (2001), Der Ruf der Sirenen - zur Dynamik politischen Benchmarkings. Eine Analyse anhand der US-Sozialreform, Discussion Paper FS II 01-201, Wissenschaftszentrum Berlin für Sozialforschung, Berlin.

Teulings, C. and J. Hartog (1998), Corporatism or Competition? Labour Contracts, Institutions and Wage Structures in International Comparison, Cambridge.

Traxler, F., B. Kittel and S. Blaschke (2001), National Labour Relations in Internationalized Markets, Oxford.

Tronti, L. (ed.) (1998), Benchmarking Employment Performance and Labour Market Policies, Berlin. 


\section{CESifo Working Paper Series}

(for full list see www.cesifo.de)

719 Tapio Palokangas, The Political Economy of Collective Bargaining, May 2002

720 Gilles Saint-Paul, Some Evolutionary Foundations for Price Level Rigidity, May 2002

721 Giorgio Brunello and Daniela Sonedda, Labor Tax Progressivity, Wage Determination, and the Relative Wage Effect, May 2002

722 Eric van Damme, The Dutch UMTS-Auction, May 2002

723 Paolo M. Panteghini, Endogenous Timing and the Taxation of Discrete Investment Choices, May 2002

724 Achim Wambach, Collusion in Beauty Contests, May 2002

725 Dominique Demougin and Claude Fluet, Preponderance of Evidence, May 2002

726 Gilles Saint-Paul, Growth Effects of Non Proprietary Innovation, May 2002

727 Subir Bose, Gerhard O. Orosel, and Lise Vesterlund, Optimal Pricing and Endogenous Herding, May 2002

728 Erik Leertouwer and Jakob de Haan, How to Use Indicators for 'Corporatism' in Empirical Applications, May 2002

729 Matthias Wrede, Small States, Large Unitary States and Federations, May 2002

730 Christian Schultz, Transparency and Tacit Collusion in a Differentiated Market, May 2002

731 Volker Grossmann, Income Inequality, Voting Over the Size of Public Consumption, and Growth, May 2002

732 Yu-Fu Chen and Michael Funke, Working Time and Employment under Uncertainty, May 2002

733 Kjell Erik Lommerud, Odd Rune Straume, and Lars Sørgard, Downstream Merger with Oligopolistic Input Suppliers, May 2002

734 Saku Aura, Does the Balance of Power Within a Family Matter? The Case of the Retirement Equity Act, May 2002

735 Sandro Brusco and Fausto Panunzi, Reallocation of Corporate Resources and Managerial Incentives in Internal Capital Markets, May 2002

736 Stefan Napel and Mika Widgrén, Strategic Power Revisited, May 2002 
737 Martin W. Cripps, Godfrey Keller, and Sven Rady, Strategic Experimentation: The Case of Poisson Bandits, May 2002

738 Pierre André Chiappori and Bernard Salanié, Testing Contract Theory: A Survey of Some Recent Work, June 2002

739 Robert J. Gary-Bobo and Sophie Larribeau, A Structural Econometric Model of Price Discrimination in the Mortgage Lending Industry, June 2002

740 Laurent Linnemer, When Backward Integration by a Dominant Firm Improves Welfare, June 2002

741 Gebhard Kirchgässner and Friedrich Schneider, On the Political Economy of Environmental Policy, June 2002

742 Christian Keuschnigg and Soren Bo Nielsen, Start-ups, Venture Capitalits, and the Capital Gains Tax, June 2002

743 Robert Fenge, Silke Uebelmesser, and Martin Werding, Second-best Properties of Implicit Social Security Taxes: Theory and Evidence, June 2002

744 Wendell Fleming and Jerome Stein, Stochastic Optimal Control, International Finance and Debt, June 2002

745 Gene M. Grossman, The Distribution of Talent and the Pattern and Consequences of International Trade, June 2002

746 Oleksiy Ivaschenko, Growth and Inequality: Evidence from Transitional Economies, June 2002

747 Burkhard Heer, Should Unemployment Benefits be Related to Previous Earnings?, July 2002

748 Bas van Aarle, Giovanni Di Bartolomeo, Jacob Engwerda, and Joseph Plasmans, Staying Together or Breaking Apart: Policy-makers' Endogenous Coalitions Formation in the European Economic and Monetary Union, July 2002

749 Hans Gersbach, Democratic Mechanisms: Double Majority Rules and Flexible Agenda Costs, July 2002

750 Bruno S. Frey and Stephan Meier, Pro-Social Behavior, Reciprocity or Both?, July 2002

751 Jonas Agell and Helge Bennmarker, Wage Policy and Endogenous Wage Rigidity: A Representative View From the Inside, July 2002

752 Edward Castronova, On Virtual Economies, July 2002

753 Rebecca M. Blank, U.S. Welfare Reform: What's Relevant for Europe?, July 2002

754 Ruslan Lukach and Joseph Plasmans, Measuring Knowledge Spillovers Using Patent Citations: Evidence from the Belgian Firm's Data, July 2002 
755 Aaron Tornell and Frank Westermann, Boom-Bust Cycles in Middle Income Countries: Facts and Explanation, July 2002

756 Jan K. Brueckner, Internalization of Airport Congestion: A Network Analysis, July 2002

757 Lawrence M. Kahn, The Impact of Wage-Setting Institutions on the Incidence of Public Employment in the OECD: 1960-98, July 2002

758 Sijbren Cnossen, Tax Policy in the European Union, August 2002

759 Chandima Mendis, External Shocks and Banking Crises in Developing Countries: Does the Exchange Rate Regime Matter?, August 2002

760 Bruno S. Frey and Lars P. Feld, Deterrence and Morale in Taxation: An Empirical Analysis, August 2002

761 Lars Calmfors and Åsa Johansson, Nominal Wage Flexibility, Wage Indexation and Monetary Union, August 2002

762 Alexander R. W. Robson and Stergios Skaperdas, Costly Enforcement of Property Rights and the Coase Theorem, August 2002

763 Horst Raff, Preferential Trade Agreements and Tax Competition for Foreign Direct Investment, August 2002

764 Alex Cukierman and V. Anton Muscatelli, Do Central Banks have Precautionary Demands for Expansions and for Price Stability? - Theory and Evidence, August 2002

765 Giovanni Peri, Knowledge Flows and Knowledge Externalities, August 2002

766 Daniel Friedman and Nirvikar Singh, Equilibrium Vengeance, August 2002

767 Sam Bucovetsky and Michael Smart, The Efficiency Consequences of Local Revenue Equalization: Tax Competition and Tax Distortions, August 2002

768 Tapio Palokangas, International Labour Market Regulation and Economic Growth with Creative Destruction, August 2002

769 Rudi Dornbusch, The New International Architecture, September 2002

770 Hans-Werner Sinn, Weber's Law and the Biological Evolution of Risk Preferences: The Selective Dominance of the Logarithmic Utility Function, September 2002

771 Thomas Mayer, The Macroeconomic Loss Function: A Critical Note, September 2002

772 Seppo Honkapohja and Kaushik Mitra, Learning Stability in Economies with Heterogenous Agents, September 2002

773 David Laidler, Inflation Targets Versus International Monetary Integration - A Canadian Perspective, September 2002 
774 Morten I. Lau, Panu Poutvaara, and Andreas Wagener, The Dynamic Cost of the Draft, September 2002

775 Steven Brakman, Harry Garretsen, and Charles van Marrewijk, Locational Competition and Agglomeration: The Role of Government Spending, September 2002

776 Anke S. Kessler and Christoph Lülfesmann, The Theory of Human Capital Revisited: On the Interaction of General and Specific Investments, September 2002

777 Kjell Erik Lommerud, Frode Meland and Lars Sørgard, Unionized Oligopoly, Trade Liberalization and Location Choice, September 2002

778 Antonio Merlo and François Ortalo-Magné, Bargaining over Residential Real Estate: Evidence from England, September 2002

$779 \mathrm{Yu}-\mathrm{Fu}$ Chen and Michael Funke, Exchange Rate Uncertainty and Labour Market Adjustment under Fixed and Flexible Exchange Rates, September 2002

780 Michael S. Michael, International Migration, Income Taxes and Transfers: A Welfare Analysis, September 2002

781 Clemens Fuest and Alfons Weichenrieder, Tax Competition and Profit Shifting: On the Relationship between Personal and Corporate Tax Rates, October 2002

782 Jan Bouckaert and Hans Degryse, Softening Competition by Enhancing Entry: An Example from the Banking Industry, October 2002

783 Johann K. Brunner and Susanne Pech, Adverse Selection in the Annuity Market with Sequential and Simultaneous Insurance Demand, October 2002

784 Gregory D. Hess and Eduard Pelz, The Economic Welfare Cost of Conflict: An Empirical Assessment, October 2002

785 Jan Erik Askildsen, Uwe Jirjahn, and Stephen C. Smith, Works Councils and Environmental Investment: Theory and Evidence from German Panel Data, October 2002

786 Geir H. Bjønnes, Dagfinn Rime, and Haakon O. Aa. Solheim, Volume and Volatility in the FX-Market: Does it matter who you are?, October 2002

787 John Evans and John Fingleton, Entry Regulation and the Influence of an Incumbent Special Interest Group, October 2002

788 Wolfgang Ochel, International Comparisons and Transfer of Labour Market Institutions, October 2002 